\title{
IMPACT OF WEATHER CONDITIONS ON THE CONSTRUCTION OF THE TERMINAL - MONTE CARLO SIMULATION
}

\author{
Tatjana Stanivuk ${ }^{1}$, Tonći Tokić ${ }^{2}$ \\ ${ }^{1}$ University of Split, Faculty of Maritime Studies, Zrinsko-Frankopanska 38, 21000 Split, Croatia \\ ${ }^{2}$ Credere d.o.o. - Tank Core Solutions, Kroz Smrdecac 41, 21000 Split, Croatia
}

Received 10 September 2012; accepted 10 December 2012

\begin{abstract}
A simulation model is developed for the potential planned Patagonia and Tierra del Fuego terminals. The purpose is to identify reliability and availability of loading operations at the terminal. The harsh weather conditions, technical reliability and concurrent traffic affect LNG (Liquefied Natural Gas) Carriers during approaching or loading. Probabilistic simulation method is created and Monte Carlo simulations are carried out for several cases, with varied production, number of jetties and terminal storage. The results indicate high importance of weather restrictions and are used to present a recommendation with two loading jetties and a larger volume of storage capacity.
\end{abstract}

Keywords: terminal, weather conditions, storage capacity, Monte Carlo simulations.

\section{Introduction}

The main expected results of the study are: quantified probability of failure in loading operations based on certain selected inputs of the system; and probability of weather and operability failures. Such results are typically useful to decision-makers who can utilize simulation results to support their decisions.

When planning port loading terminals at locations with severe weather conditions, it is necessary to define both the economical and the climatic aspects. The construction of the loading terminal in Tierra del Fuego is a demanding endeavour particularly due to extremely severe weather conditions characteristic for the area.

In order to support the decision making process, the information on potential unreliability of loading operations are vital. There is a lack of practical experience available for operations which are planned for Patagonia and Tierra del Fuego, and therefore a study has been conducted to provide estimates regarding this issue. Finally, most of the new potential reserves that exist in Argentina are located in the south of the country (in Patagonia and Tierra del Fuego) and offshore. These are areas that are difficult to access and require significant investment, which Repsol YPF was not prepared to make, due to its financial situation. Instead, the company gave preference to utilizing its large reserves in Bolivia that were much easier to access (Abadie and Chamorro, 2009).

It is possible to quantitatively represent uncertainties in simulations. Probabilistic simulation is the process of explicitly representing these uncertainties by specifying inputs as probability distributions. If the inputs describing

${ }^{1}$ Corresponding author: tstanivu@pfst.hr 
a system are uncertain, the prediction of future performance is necessarily uncertain. That is, the result of any analysis based on inputs represented by probability distributions is itself a probability distribution. This type of probabilistic simulation is often referred to as the Monte Carlo method and is the selected method to be used in this study. Taking into account the planned production and terminal construction in Tierra del Fuego area, this study aims to evaluate several operations related to commodity loading and export such as:

- $\quad$ Production per day;

- $\quad$ Storage capacity;

- Loading rate per day;

- Vessel speed and voyage time.

\section{Model of the Tierra del Fuego Complex}

Using the described model, different ways to improve the terminal facility's availability due to weather conditions could be proposed and tested. The model will also be used to determine the effect of the offshore dredging and construction work during the LNG train facility development. The main purpose of the availability study is to develop a computer model of the complete terminal complex to assess the overall availability of the related commodity loading and shipping operations, and to provide assistance in understanding the contribution of different systems to the overall terminal unavailability. The simulation for the Terminal includes the following units: LNG production facility, LNG terminal storage, loading jetty and arms, LNG tankers and icebreakers (Fig. 1).

The computer model was developed using the software package Multiphysics, a general purpose modelling software. The purpose-built model was programmed for this study. The program predicts the performance of a system

\section{LNG Development - Cost Breakdown}

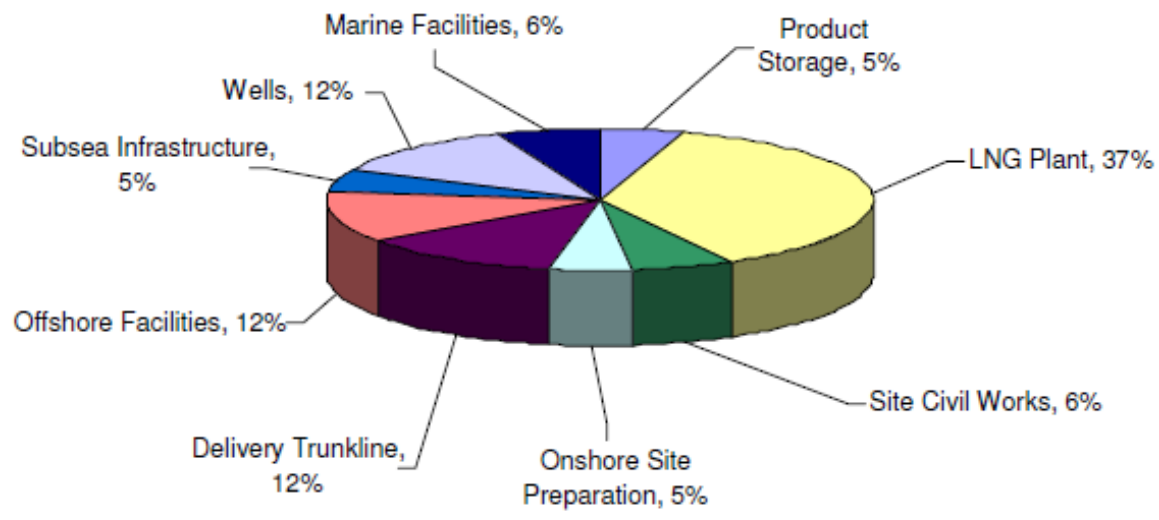

Fig. 1.

LNG Development Cost Breakdown 
through application of a discrete event based system model that will simulate life-cycle scenarios of terminal operations. The system must include the reliability of the units based on general historical data or the experts' best judgement. The operating policies are also included in the model. The computer model can be run though a life-cycle of the terminal. Since the model includes events which are set by a random generator, each of them produces a different result. Based on the Monte Carlo method, the system must be run through a sufficient number of times in order to generate probability function. Typically more than 100 simulations are required.

Environmental and failure data contained within the model are described by different distribution functions, i.e. exponential, normal, triangular or rectangular. In cases where terminal complex interactions between elements of the model are required, conditional logic is used to ensure good representation of the planned real world operations (for example icebreaker support). In addition to the unscheduled events, all major known activities are included as scheduled events at the required frequency (in years) and duration (in hours). The known weather conditions, maintenance and terminal production parameters which are changing annually are included in the model as controlling elements (Fig. 2).

\section{Basic Mapping Project Assumptions}

The main assumptions in the computer model are: Cargo Terminal life-cycle is 25 years, LNG facility input is $35000 \mathrm{~m}^{3}$ /day per single train, LNG storage tanks capacity is $350000 \mathrm{~m}^{3}$, Number of loading jetties (1-3), LNG loading rate is $8000 \mathrm{~m}^{3} / \mathrm{h}$, Berthing takes nominally 2-4 hours depending on the season, Approach is supported by icebreaker tug boats (maximum of $25 \mathrm{Nm}$ ), LNG carriers is capable of handling

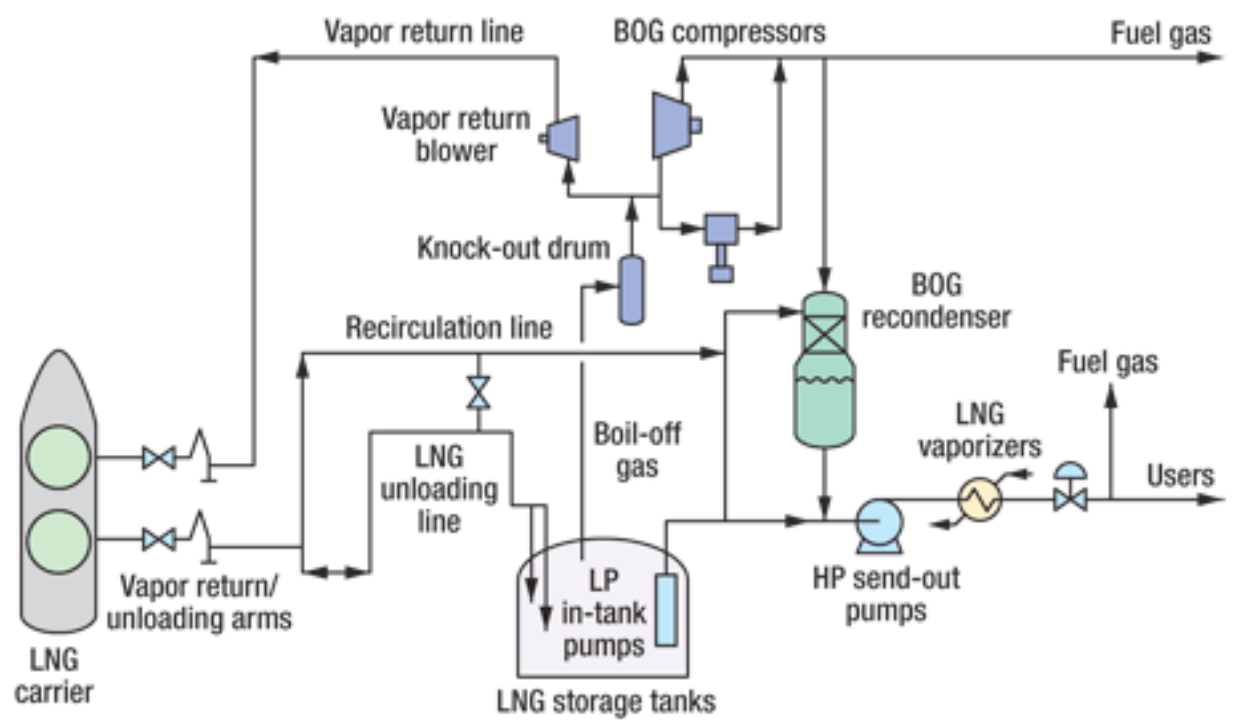

Fig. 2.

Designing the LNG Terminal of the Future

Source: Lemmers (2009) 
all vapour during loading, Connection of the loading arms takes 3 hours, One line icebreaker is used at the entrance, 4 tug boats in summer time and Dredging.

Other items, operative functions or poorly defined environmental criteria which do not have a direct influence on the terminal are excluded from the model.

\section{Weather Related Influences}

\subsection{Temperature}

The air temperature is set to average monthly temperature, with variations between minimum and maximum. Normal distribution is used (Fig. 3 and Fig. 4).

The temperature is affecting the following events: loading arm connection time and berthing time.

\subsection{Wind Speed}

Wind information is available from the Antarctica meteorological station and the data is used to represent Tierra del Fuego conditions at the terminal location and offshore for the approach sea ways (Fig. 5).

The material losses caused by wind conditions are divided into following categories:

- The wind speed is having adverse effects and causing delays during the approach of the vessel in cases when it exceeds $15 \mathrm{~m} / \mathrm{s}$;

- Considering cases when wind speed exceeds $12 \mathrm{~m} / \mathrm{s}$, it is expected to experience delays during approach of the vessel by $20 \%$, due to higher ice compression;

- If the wind speed exceeds $25 \mathrm{~m} / \mathrm{s}$, it is expected to delay the sea voyage by 6 hours;

- In cases when wind speed exceeds $15 \mathrm{~m} / \mathrm{s}$, it is prohibited to enter the Tierra

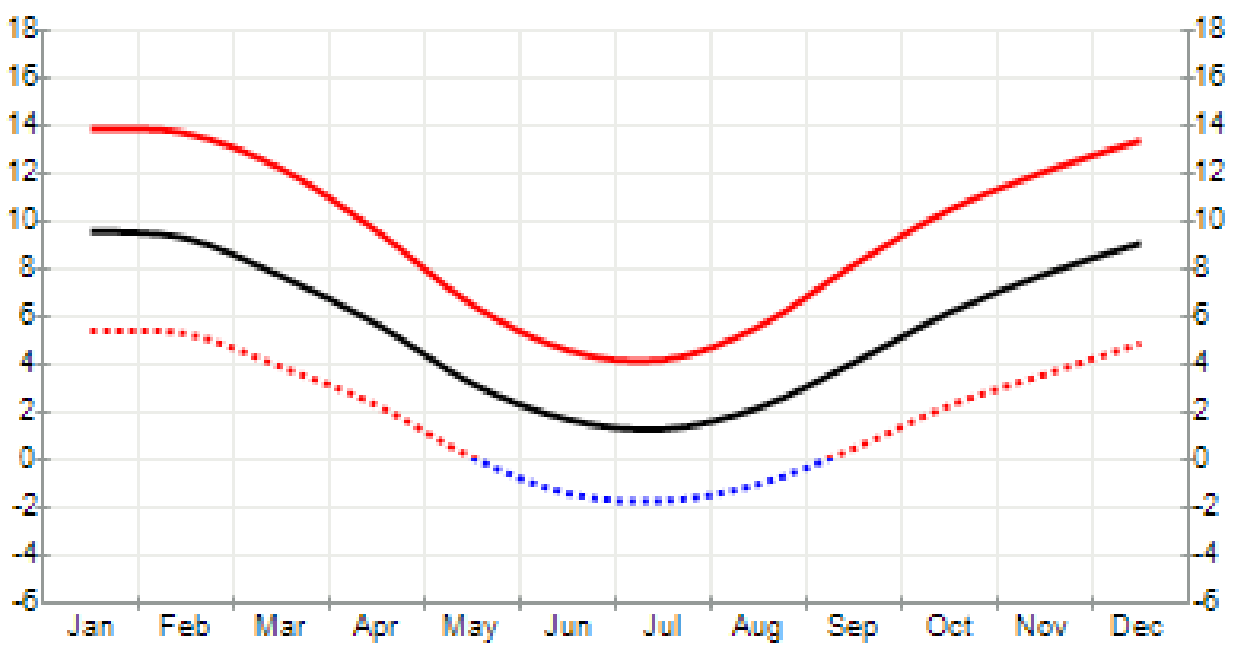

Fig. 3.

Average Temperature per Month

Source: National Weather Service (2007) 


\begin{tabular}{|c|c|c|c|}
\hline \multirow[b]{2}{*}{ Months } & \multicolumn{3}{|c|}{ Temperature } \\
\hline & Normal & Warmest & Coldest \\
\hline Jatuery & $96 \mathrm{C}$ & $139^{\circ} \mathrm{C}$ & $54 \mathrm{CC}$ \\
\hline fetruary & 920 & $12 . T^{*} \mathrm{C}$ & $5.2^{2} \mathrm{c}$ \\
\hline Boreh & 7.746 & $122^{\circ} \mathrm{C}$ & 3.915 \\
\hline Apri & 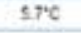 & $\$ 6^{\circ} \mathrm{C}$ & $23^{\circ} \mathrm{C}$ \\
\hline voy & $32^{\circ} \mathrm{C}$ & $65^{\prime} \mathrm{C}$ & $0.18 \mathrm{C}$ \\
\hline tene & $17 \mathrm{C}$ & 480 & $14 \mathrm{C}$ \\
\hline juy & 130 & $42^{\circ} \mathrm{C}$ & -1.70 \\
\hline Avaust & $22^{\circ} \mathrm{C}$ & 560 & -1006 \\
\hline September & $41^{\prime} \mathrm{C}$ & $3.26 \mathrm{C}$ & 0.50 \\
\hline Octoter & $6 \mathrm{JPC}$ & $10 \mathrm{sic}$ & $29 \mathrm{C}$ \\
\hline Neventeer & $78 \mathrm{C}$ & $121+\mathrm{C}$ & $3.00 \mathrm{C}$ \\
\hline Decontsen & 018 & $130 \mathrm{c}$ & $4 \mathrm{ve}$ \\
\hline
\end{tabular}

Fig. 4.

Tabular View for Temperature and Precipitation per Month

Source: National Weather Service (2007)

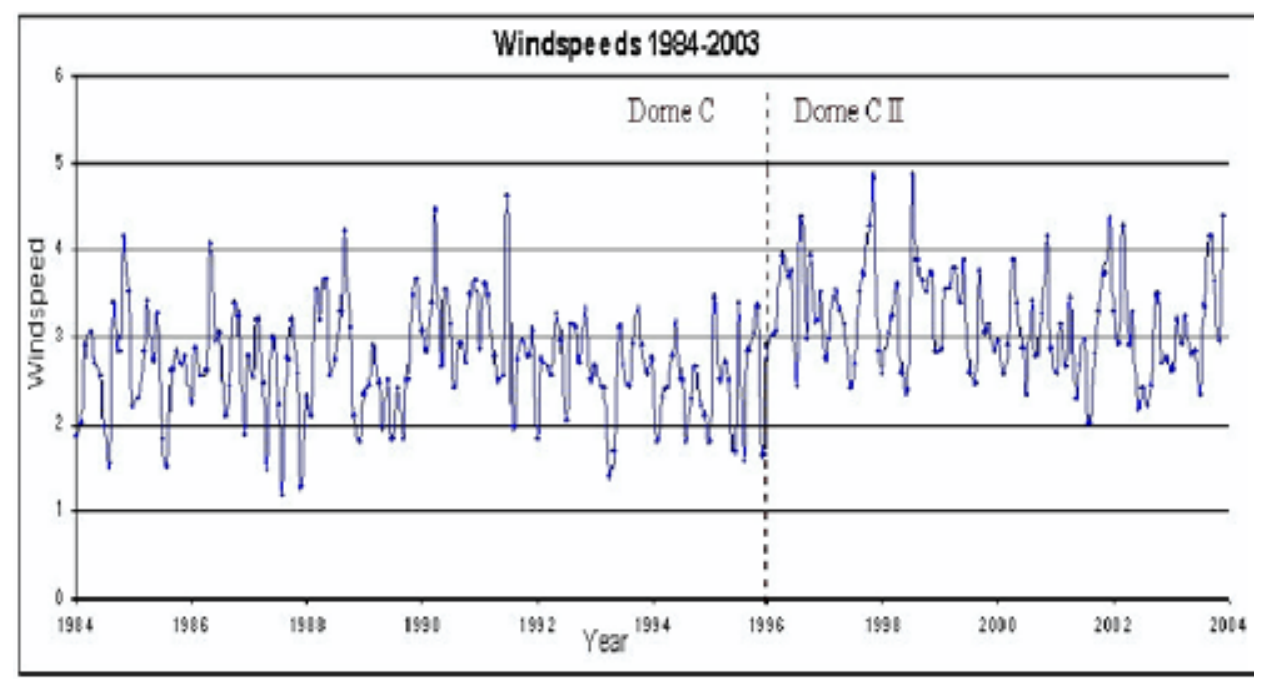

Fig. 5.

Monthly Wind Speed at Antarctica (1984 - 2003)

Source: Aristidi et al. (2004)

\section{Table 1}

Number of Days with Fog

\begin{tabular}{|l|c|c|c|c|c|c|c|c|c|c|c|c|}
\hline MONTH & I & II & III & IV & V & VI & VII & VIII & IX & X & XI & XII \\
\hline Average & 2 & 3 & 3 & 5 & 5 & 7 & 9 & 7 & 7 & 4 & 3 & 3 \\
\hline Maximum & 5 & 8 & 7 & 10 & 11 & 12 & 13 & 12 & 11 & 10 & 9 & 7 \\
\hline Heavy fog, average & 1.0 & 1.0 & 1.0 & 1.0 & 2.0 & 2.5 & 3.3 & 2.3 & 1.8 & 1.1 & 1.0 & 1.0 \\
\hline
\end{tabular}


del Fuego approach channel and LNG carrier must wait in the safe place outside the approach channel. LNG carrier is also not allowed to leave the port.

\subsection{Impact of Visibility Reduced by Fog}

One of the important aspects of marine safety and approach of the vessel to the loading terminal is reduced visibility that may be caused by fog. In view of the fact that all vessels must be adequately equipped for sailing in conditions of reduced visibility, the permission for berthing and approach of the vessel to the terminal shall be confirmed by the terminal operator. Approach and leaving of vessels from the terminal shall be limited if the visibility is less than 100 meters. Severe fog may be expected during $1 / 3$ of the time indicated in Table 1.

\subsection{Rain/Snow Precipitation}

It is shown that rain/snow precipitation has no effect on the model (Rosenbluth et al., 1997).

\subsection{Ice}

In this section, only a summary of the most important values reflected in the simulation model is presented. Ice conditions (Jones et al., 1994; Jones, 1995) vary significantly and therefore have a strong effect on the transport and loading operability (Table 2 ). The following unscheduled events may occur: delay in sea voyage, delay in approach and delay in icebreaker support.

The delay in sea voyage is difficult to relate to known data on ice conditions, therefore reference data from existing ships operating in same region were used. It should also be mentioned that LNG carriers which operate today on ice-free routes are able to follow their planned schedules adequately (King, 1994). The following data is generated based on data on previous similar voyages: average speed $10.35 \mathrm{kt}$, maximum average speed $11.45 \mathrm{kt}$, minimum average speed $9.64 \mathrm{kt}$, with rectangular distribution type. The speed must be changed with time, and the corresponding values based on 150 nautical miles ice distance are: deviation from average maximum 3.2 hours and deviation from average minimum 4.1 hours. Otherwise it is expected that there is a suitable number of LNG carriers available, so that they are able to arrive at the LNG terminal in accordance with the planned schedule.

\section{Probability of Technical Failures}

The LNG loading operations represent a technically demanding endeavour requiring

Table 2

Ice Season

\begin{tabular}{|l|l|l|}
\hline \multirow{2}{*}{ Freeze - up: } & Average & Early November \\
\cline { 2 - 3 } & Earliest & Early October \\
\cline { 2 - 3 } & Latest & Late December \\
\hline \multicolumn{2}{|l}{} \\
\hline \multirow{2}{*}{ Break - up: } & Average & Late May \\
\cline { 2 - 3 } & Earliest & Early April \\
\cline { 2 - 3 } & Latest & Late July \\
\hline
\end{tabular}


a specific approach. One of the following events may have adverse effects on loading operations:

1. Malfunction of the loading arm would cause delays in loading, lasting approximately five days, i.e. the time period required for repair;

2. Malfunction of the loading pumps and the entire related technical system would cause delays in sea voyage.

The probability of stated events at modern ships is approximately 0.002 events per year, considering the total annual number of malfunctions in LNG operations. Using the available data provided by the LNG shipping companies, it is evident that LNG ships are active at loading/discharging operations and sea voyage during $99.8 \%$ of the total time at sea. The stated information is included in the simulation in order to obtain the optimal availability value of the loading terminal during the time period of one year.

\section{Study Cases, Results and Conclusions}

The following cases are analysed in Table 3.

Table 3

Study Case

\begin{tabular}{|l|l|}
\hline \multirow{2}{*}{ Phase 1 production } & 1 loading jetty \\
\cline { 2 - 2 } & 2 loading jetty \\
\hline \multirow{3}{*}{ Phase 2 production } & 1 loading jetty \\
\cline { 2 - 2 } & 2 loading jetty \\
\cline { 2 - 2 } & 3 loading jetty \\
\hline \multirow{3}{*}{ Phase 3 production } & 1 loading jetty \\
\cline { 2 - 2 } & 2 loading jetty \\
\cline { 2 - 2 } & 3 loading jetty \\
\hline
\end{tabular}

Source: According to Authors' Analysis

\subsection{Stability of the Monte Carlo Simulation}

The selection of the optimal LNG terminal site variant should start from an analysis of navigational risks on waterways leading to the examined LNG terminal variants. The navigational risk analysis aims at identifying the kinds of accidents that may happen to an LNG tanker proceeding along particular sections of the waterway leading to any of the terminal variant sites. The analysis of navigational risks in reference to LNG carriers allows determination of the following three types of waterway: open sea waterway (shipping routes); the prevailing risk is a collision of an LNG tanker with another vessel; coastal waterway; this is usually a fairway leading from an anchorage to entrance heads of the port, along which the prevailing risk is grounding in shallow water or on a slope of the fairway channel; waterway crossing port waters, where the vessel will be mainly manoeuvring while entering the port and approaching the terminal, turning and mooring; a risk involves LNG tanker's collision with a marine port structure, area bottom or another vessel or vessels berthing in the port (Fig. 6).

Taking into account the accumulated information from Phase 1 cases, it can be seen that after 100 simulation runs the results of availability start to stabilize (Stanivuk and Tokić, 2012). The plot line shows the cumulative average of the individual simulation cases. It can be identified that it stabilizes after 50 simulation runs and therefore it can be concluded that 100 runs should be sufficient (Fig. 7 and Fig. 8). Availability of Punta Arenas terminal will be expected to have a mean value of $83.2 \%$. A similar plot is shown also for the Phase 3 simulation case. 


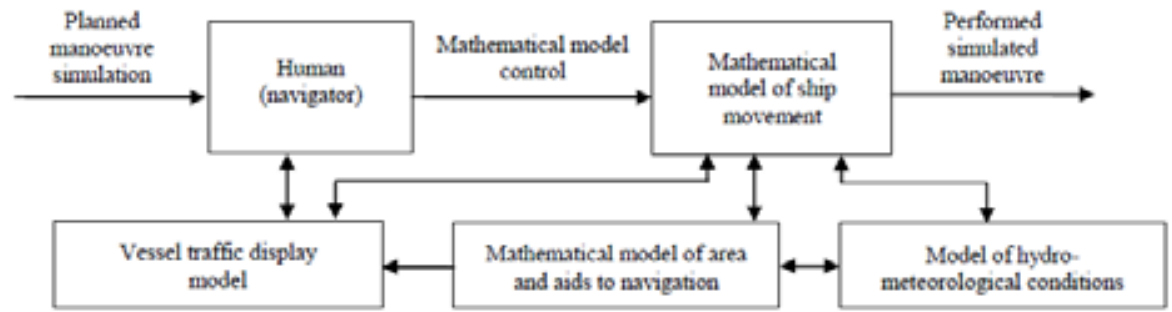

Fig. 6.

Non-Autonomous Simulation Model of Ship Movement in Restricted Areas

Source: Gucma (2011)

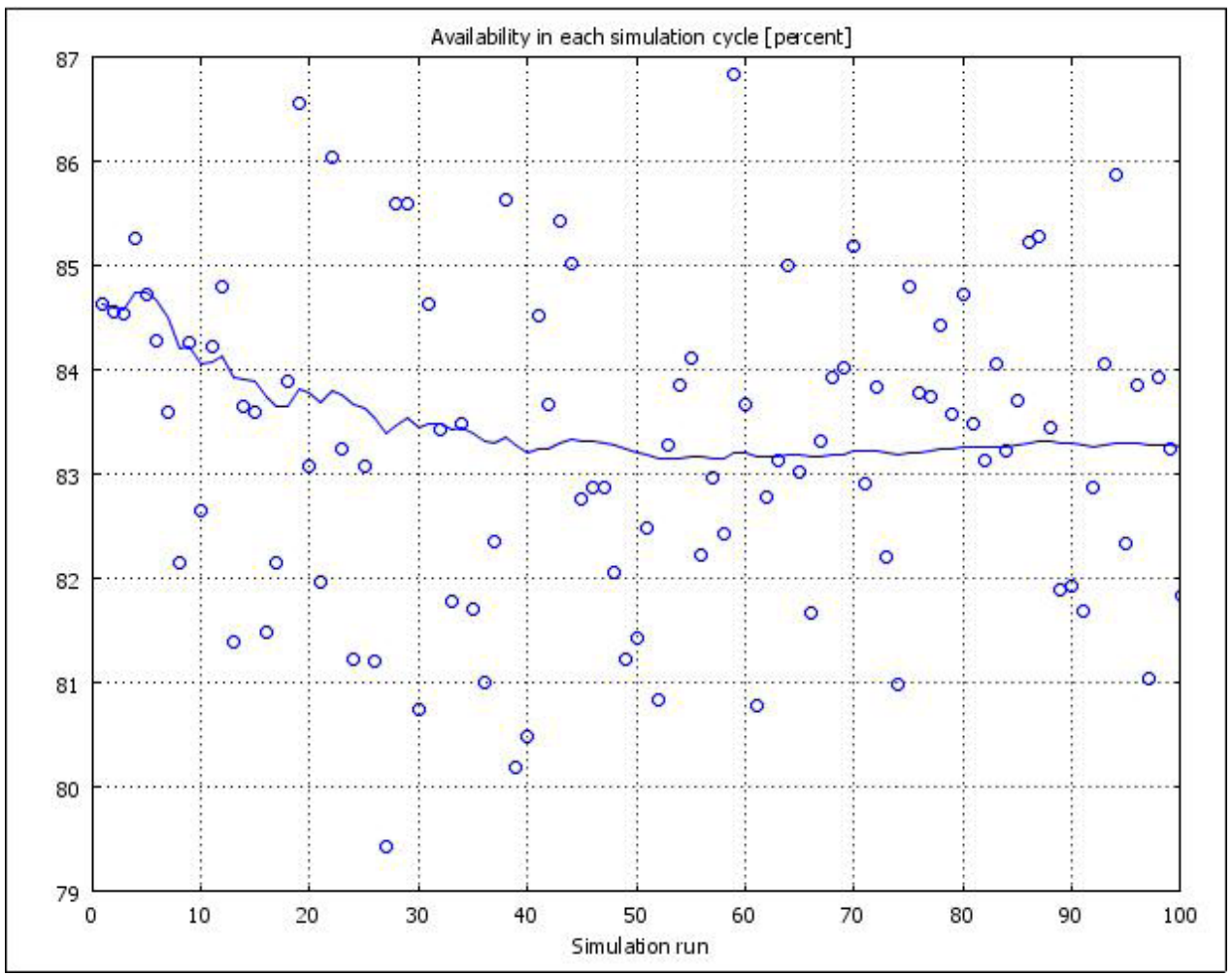

Fig. 7.

Result of MC-Simulations Running 100 Times. Terminal Availability Percentage (Phase 1) 


\subsection{Terminal Availability Results and Problems Identified in Simulations}

This method was used in the process of planning the location of the LNG terminal. Two LNG tankers were used for the testing.

Methods in real time are also used to define the kinetic energy of gas carrier berthing for a selected set of cargo handling berths at the LNG terminal.

Availability is defined to be the relative time during which weather, damage, delay or occupation of the entrance channel limits the approaching or loading operations.

Probability of overfill of storage tanks is the time during which storage exceeds the set limit value (i.e. $350000 \mathrm{~m}^{3}$ ).

The results of simulated case are given in Table 4.

Further analysis of the results will be required to evaluate the reasons and means of improvement. Authors shall also investigate how these values depend on the level of stochastic variability in the shipping model, the type of LNG carriers model used, the LNG throughput, and the type of inventory control policy employed.

\subsection{Recommendations}

Motivated by the current developments in the LNG industry, authors developed a real option model for the strategic valuation of LNG terminal storage. Unique to this model is the integration of terminal models of natural gas liquefaction and LNG shipping, natural gas price evolution, and LNG inventory and sale into the wholesale spot market. This provides a heuristic strategic valuation of the real option to store LNG at the terminal. Authors applied the model to real and estimated data.

The probability of terminal availability is dominated by the weather conditions. Therefore, no significant improvement can be made by adding more loading arms or loading jetties. It is evident (Table 4) that the increase in production leads to an increase in demand for larger storage space. The recommendation would be to prevent potential failures in storage and production systems by increasing the cargo loading frequency, as presented in Phase 1 to Phase 3. This approach would enable failurefree production process. Vessels delay on arrival will affect storage capacity and increase risk of overfilling the cargo storage tanks.

The number of loading jetties, on the other hand, has a clear and positive influence on the probability of overfilling the storage tanks.

The results of this study show the importance of the weather conditions, namely the ice, wind and fog. However, the reliability of the information used should be crosschecked from various sources, obtaining more specific statistical data.

Based on the analysis, it seems that the best solution would be to install two loading jetties already in Phase 1 and gradually increase the storage capacity. The nominal capacity of $350000 \mathrm{~m}^{3}$ is not deemed sufficient for Phase 3 production, consequently doubling up of the capacity is recommended, as well as installing two loading jetties. The simulation carried out for the purpose of this paper indicates the possible solution for vessel delay at loading terminals, by increasing the storage capacity. In this manner, the safety aspects in the distribution of the liquefied gas at the terminal, thus avoiding disruptions in the production process. 


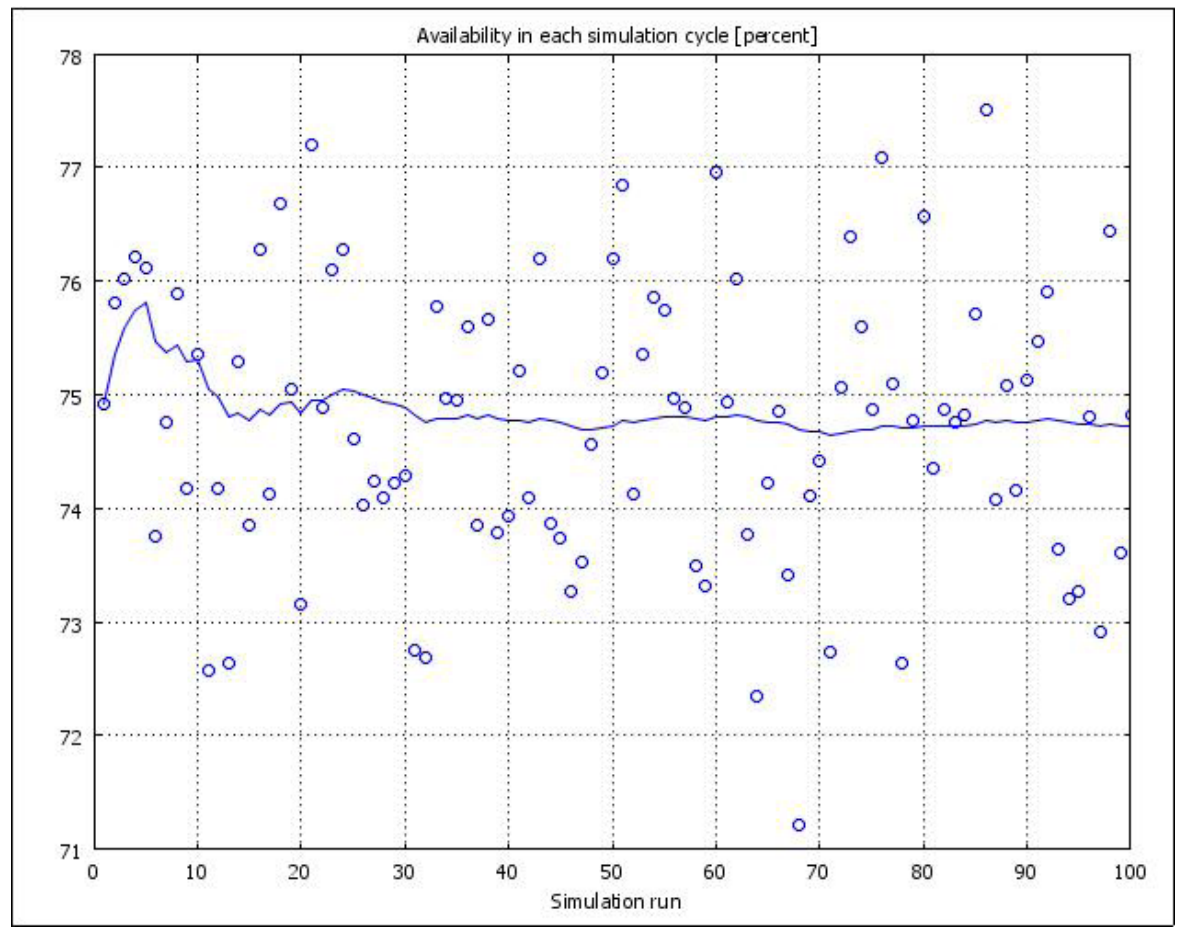

Fig. 8.

Result of MC-Simulations Running 100 Times. Terminal Availability Percentage (Phase 3)

Table 4

Availability Percentage and Probability of Overloading Storage

\begin{tabular}{|l|c|c|c|c|}
\hline CASE & $\begin{array}{c}\text { Number of } \\
\text { jetties }\end{array}$ & $\begin{array}{c}\text { Availability Mean } \\
\text { (min-max) }\end{array}$ & Limit of overfill & $\begin{array}{c}\text { Probability of overfill } \\
\text { \% of time) }\end{array}$ \\
\hline Phase 1 & 1 & $82.5 \%(79.0-86.0 \%)$ & $350000 \mathrm{~m}^{3}$ & $1.17 \%$ \\
\hline Phase 1 & 2 & $83.1 \%(79.4-86.8 \%)$ & $350000 \mathrm{~m}^{3}$ & $0.06 \%$ \\
\hline & & & & $3.33 \%$ \\
\hline Phase 2 & 1 & $77.9 \%(74.0-86.8 \%)$ & $350000 \mathrm{~m}^{3}$ & $1.26 \%$ \\
\hline Phase 2 & 2 & $79.0 \%(75.0-83.0 \%)$ & $350000 \mathrm{~m}^{3}$ & $0.97 \%$ \\
\hline Phase 2 & 3 & $79.0 \%(75.0-83.0 \%)$ & $350000 \mathrm{~m}^{3}$ & \\
\hline & & & & $8.19 \%$ \\
\hline Phase 3 & 1 & $74.2 \%(71.0-77.5 \%)$ & $350000 \mathrm{~m}^{3}$ & $3.38 \%$ \\
\hline Phase 3 & 2 & $74.5 \%(71.0-78.0 \%)$ & $350000 \mathrm{~m}^{3}$ & \\
\hline Phase 3 & 3 & $74.5 \%(71.0-78.0 \%)$ & $350000 \mathrm{~m}^{3}$ & \\
\hline & & & & $0.40 \%$ \\
\hline Phase 3 & 1 & $74.0 \%(71.0-77.0 \%)$ & $640000 \mathrm{~m}^{3}$ & $0.06 \%$ \\
\hline Phase 3 & 2 & $75.3 \%(72.3-78.3 \%)$ & $640000 \mathrm{~m}^{3}$ & $0.07 \%$ \\
\hline Phase 3 & 3 & $75.0 \%(72.0-78.0 \%)$ & $640000 \mathrm{~m}^{3}$ & \\
\hline
\end{tabular}

Source: According to Authors' Analysis 


\section{References}

Abadie, L.M.; Chamorro, J.M. 2009. Monte Carlo valuation of natural gas investments, Review of Financial Economics. DOI: http://dx.doi.org/10.1016/j.rfe.2008.10.002, 18(1): $10-22$.

Aristidi, E.; Agabi, K.; Azouit, M.; Fossat, E.; Vernin, J.; Travouillon, T.; Lawrence, J.S.; Meyer, C.; Storey, J.W.V.; Halter, B.; Roth, W.L.; Walden, V. 2004. An analysis of temperatures and wind speeds above Dome $\mathrm{C}$, Antarctica. Available from Internet: <http://www-luan.unice. $\mathrm{fr} / \sim$ aristidi/articles/aa_wind.pdf $>$.

Gucma, S. 2011. Simulation methods in LNG terminal design, Scientific Journals Maritime University of Szczecin, 25(97): 28-34.

Internet Services Group. 2007. National Weather Service. Available from Internet: <http://weather.noaa.gov/ weather/CL_cc.html>.

Jones, P.D.; Wigley, T.M.L.; Briffa, K.R. 1994. Global and hemispheric temperature anomalies - land and marine instrumental records. In Boden, T.A.; Kaiser, D.P.; Sepanski, R.J.; Stoss, F.W. (eds), Trends '93; A Compendium of Data on Global Change, ORNL / CDIAC-65, Carbon Dioxide Information Analysis Center, Oak Ridge National Laboratory, Oak Ridge, Tn. 603-608.

Jones, P.D. 1995. Recent variation in mean temperature and the diurnal temperature range in the Antarctic, Geophysical Research Letters, 22(11): 1345-1348.

King, J.C. 1994. Recent climate variability in the vicinity of the Antarctic Peninsula, International Journal of Climatology. DOI: http://dx.doi.org/10.1002/joc.3370140402, 14(4): 357-369.

Lemmers, S.P.B. 2009. Designing the LNG terminal of the future. Available from Internet: <09-09_Lemmers_fig1.gif $>$.
Rosenbluth, B.; Fuenzalida, A.; Aceituno, P. 1997. Recent temperature variations in southern South America, International Journal of Climatology. DOI: http://dx.doi. org/10.1002/(SICI)1097-0088(199701)17:1<67::AIDJOC120>3.0.CO;2-G, 17(1): 67-85.

Stanivuk, T.; Tokić, T. 2012. How to predict cargo handling times in sea port affected by weather conditions. In Proceedings of the 14th International Conference on Operational Research, Trogir, Croatia. 26-28.

UTICAJ VREMENSKIH USLOVA NA IZGRADNJU TERMINALA - MONTE CARLO SIMULACIJA

\section{Tatjana Stanivuk, Tonći Tokić}

Sažetak: U radu je razvijen simulacioni model za planiranje terminala Patagonia i Tierra del Fuego. Model je namenjen određivanju pouzdanosti i raspoloživosti procesa utovara na terminalu na osnovu parametara koji se odnose na oštre vremenske uslove, tehničku pouzdanost i uticaj konkurentnog transporta ostalih prevozioca LNG (tečnog prirodnog gasa) tokom pristajanja ili utovara. U ovom radu je primenjena metoda probabilističke simulacije bazirana na Monte Karlo simulaciji za nekoliko slučajeva u zavisnosti od broja gatova i mogućnosti skladištenja opasnih tereta na terminalu. Dobijeni rezulati koji ukazuju na veliku važnost ograničenja koja nastaju usled vremenskih prilika su iskorišćeni za definisanje preporuka koje podrazumevaju dva gata za punjenje i veći kapacitet skladišnog prostora.

Ključne reči: terminal, vremenski uslovi, kapacitet skladišnog prostora, Monte Karlo simulacija. 